\title{
Influencing factors in doing business: The case of oil palm smallholders
}

Azhar Ahmad 1, *, Ahmad Rafis Che Omar ${ }^{1}$, Md Shafiin Shukor ${ }^{1}$, Lokhman Hakim Osman ${ }^{1}$, Norazlan Alias ${ }^{1}$, Mara Ridhuan $^{1}$, Suraiya Ishak ${ }^{2}$, Mohd Abdullah Jusoh ${ }^{3}$

${ }^{1}$ Faculty of Economics and Management, Universiti Kebangsaan Malaysia, Bangi, Malaysia ${ }^{2}$ Faculty of Social Sciences and Humanities, Universiti Kebangsaan Malaysia, Bangi, Malaysia ${ }^{3}$ Faculty of Management and Economics, Universiti Pendidikan Sultan Idris, Tanjung Malim, Malaysia

\section{A RT I C LE IN F O}

Article history:

Received 15 February 2017

Received in revised form

20 July 2017

Accepted 20 July 2017

Keywords:

Factors in business

Entrepreneurships

Smallholders

\begin{abstract}
A B S T R A C T
Agricultural industry such as oil palm is facing the market volatility and economic oppression. This resulted in volatility of oil palm planter's revenue. One way to make up the shortfall in revenue is to get them involved in business. However, the involvement of oil palm smallholders is not only influenced by economic factors alone, but also influenced by the push and pull factors. Therefore, the study included 178 smallholders who were currently doing business in Johor, Selangor, Perak and Sarawak. Analysis was done by Structural Equation Model (SEM) using SmartPLS software. The study found that the respondents engaged in business with the push and pull factors. Overall, the respondents expressed that "risk / challenges management" is the most important push factor followed by "leadership skill", "business opportunity", "family encouragement" and "income level". Meanwhile, "attend training" is the most important pull factor followed by factors of "infrastructure facilities" and "finance".
\end{abstract}

(C) 2017 The Authors. Published by IASE. This is an open access article under the CC BY-NC-ND license (http://creativecommons.org/licenses/by-nc-nd/4.0/).

\section{Introduction}

Business is one way to earn supplementary income. Smallholders' participation in business is a proactive step towards improving their revenues and cost of living. Business activities are important elements to develop the economy of local communities to support the growing cost of living.

Agricultural industry such as oil palm is facing the volatility of market and economic oppression. In 2012, demand for palm oil has fallen causing crude oil prices (CPO) at RM2764 per ton. Prices continued to fall in 2013 and 2014 at RM2383.50 and RM2119.50 respectively. Farmers also face pressure in their plantations because the majority of small farmers occupy only 3.9 hectares of land per family (MPOB, 2014). This resulted in income from oil palm industry in Malaysia to decrease. In fact, this directly hit the revenue of oil palm smallholders. These factors encouraged farmers to engage in other business. However, studies on the involvement of individuals in business are not only driven by economic factor, but they are also influenced by

\footnotetext{
* Corresponding Author.

Email Address: azah@ukm.edu.my (A. Ahmad)

https://doi.org/10.21833/ijaas.2017.09.014

2313-626X/C 2017 The Authors. Published by IASE.

This is an open access article under the CC BY-NC-ND license

(http://creativecommons.org/licenses/by-nc-nd/4.0/)
}

other factors such as business opportunities, knowledge, risks, facilities and finance. Therefore, this study was conducted to identify the push and pull factors encouraging farmers to get involved in business. The study will present the entrepreneurship factors for people who want to engage in business.

\section{Literature review}

Generally, motivation is an important factor in generating and linking reaction, response or action to the activities of a particular stimulus. Motivation is the psychological needs and desires of human beings in every way. People get involved in the business is due to several reasons, causes and environmental influences. Theory of reasoned action (TRA) states that motivation is influenced by some reasons or causes (Fishbein and Ajzen, 1977). This means the process of formation of motivation involves interaction between individual's belief systems with consideration or evaluation related matter, where the reaction will establish the reasons that drive a behavior. Motivation of individuals involved in the business is divided into two main components, namely pull motivation and push motivation. Pull motivation emphasis on the needs and emotions of individuals. This motivation is to answer the question of why people want to get 
involved in the business. According to a study conducted by Kuzilwa (2005), individuals engaged in business because they want to add to their family income. This factor is the main pushing factor because business is considered a contributor to revenue for survival (Salleh et al., 2016).

Motivational push is also driven by the business opportunities that are available in an area (Alvarez and Busenitz, 2001). For individuals who wish to engage in business, they will look at economic conditions and the demand of goods by consumers. After few observations and identification, then individuals will try to set up the demand for goods among the users (Rose et al., 2006). Therefore, individuals will take the opportunity to go into business (Indarti and Langenberg, 2004). Studies conducted by Rose et al. (2006) showed that economic environment and the understanding of the market needs and consumer goods became the deciding factor of the individual involved in business. Individuals should also identify areas or business site which is suitable for business premises due to the selection of the appropriate spaces will encourage business activities (Page et al., 1999). Therefore, the understanding and the facility provided is important to strategies the complex market.

Encouragement from family is one of motivational pushes for individuals to engage in business (Rose et al., 2006). Studies showed that individuals that involved in business were due to business inheritance from parents and they see that business can be developed and expanded. In addition, the availability of family-business site for operation during transaction also affects individual's involvement in business. Factors such as knowledge and skills are also important in support for business development (Yew and Aspinwall, 2004). Individuals need to know the management techniques in the business such as the financial position and capital management (Vinten, 2000).

According to Emin (2000), knowledge is an important asset to influence innovation and competitiveness in business. Personal characteristics also contributed to the push motivation of the individual engagement in business. This element refers to the action of individuals and a strong contributor for individuals to get involved in business (Gadar and Yunus, 2009; Smit and Watkins, 2012) and this factor refers to the ability of a person to operate the business (Santrock, 2007) and can be expanded if the business is handled properly (Zapalska et al., 2015).

According to studies conducted by Mazdan and Khiri (2014), individuals' action involved in business because it has the characteristics of a maturity, knowledge and ability to solve problems and make decisions. Personal features also include aspects of self-confidence which individual able to manage risk and liability in connection with the business. Selfconfidence is important to control and manage the personal and business affairs.
External factors look at the contributions of external support to individuals involved in business. External support consists of 3 main elements which are training, infrastructure and finance. Elements of training in business it is important to start a business where entrepreneurs need to know about the marketing methods, financial management, technical and business management (business strategy) in order to maintain the continuity and growth of the business (Corso et al., 2003). Proper training enables them to become more efficient and will help create maximum profit (Fuller, 1994). Infrastructure facilities such as sites, machine, water, electricity and Internet are also key factors to start a business (Jutla et al., 2002).

Finance is crucial to start a business (Walker and Brown, 2004). Financial resources can be obtained from the assistance of the government and financial institutions. According to Kolawole and Torimiro (2005), government plays an important role to assist individuals to involve in business. However, studies conducted by Azhar et al. (2015) showed that business activity in rural areas does not require loans and financial assistance because of its size. Therefore, the financial resource requirements depend on the factor of location and nature of business activities.

\section{Methodology}

This study uses data obtained from questionnaires distributed to oil palm smallholders in some selected locations in Malaysia. Locations of the study include in the area of Johor, Selangor, Perak and Miri, Sarawak which have many smallholders who get guidance from Malaysia Palm Oil Board (MPOB, 2014). The selection of the sample of respondents to represent the population studied is performed from stratified random sampling. This amount is determined based on the justification that the amount deemed sufficient to represent a population of oil palm smallholders in each district.

Questionnaires which comprised 3 sections were distributed to the respondents. The first section is on the demographic details of the oil palm's farmers. The second part is related business profiles of the smallholders. Third part is related on the push factors and the involvement of the respondent in the business. Push factors are divided into six (6) key elements including opportunities, family, income, knowledge and skills, risk management/challenges and leadership qualities. Meanwhile, pull factors are divided into three (3) namely training, infrastructure and finance. All these factors are based on the arguments in past research and modified to suit the location and objectives of the study. The questions used five-point likert scale ranging from 1 "very unimportant" to 5 "very important".

Analysis was done using Structural Equation Models (SEM) with SmartPLS software. SEM was used to analyze the relationship between variables with linear equation representing the relationship of cause and effect between the variables. SEM covers 
four main analyses which are descriptive statistics (mean), Exploratory Factor Analysis (EFA), evaluation of the measurement model and test path coefficient. Descriptive statistic test covers frequency and mean. EFA evaluates items outer loading while the assessment of the measurement model using Cronbach Alpha (CA) test, composite reliability (CR) and The Average Variance Extracted (AVE) are used to assess the validity of the data. Finally, path coefficient test is done to test the status of relationship and interests between the variables.

\section{Findings and discussion}

\subsection{Demographic profiles of respondents}

From Table 1, 85.4\% of them are men. In terms of race, $62.9 \%$ are Malays and $22.5 \%$ are Ibans. Chinese and Bugis respondents are $12.4 \%$ and $2.2 \%$ respectively. In terms of marital status, 54 of them are married and 16 are single.

Majority of the respondents have between 4-6 children which is $50.6 \%$. In education, $71.4 \%$ of the respondents have secondary school education. In terms of employment, most of them are selfemployed i.e. 152 people $(70.8 \%)$. A total of $47.6 \%$ of the respondents have a monthly income of between RM100-RM1000.

Table 1: Demographic profiles of smallholders ( $\mathrm{N}=178)$

\begin{tabular}{|c|c|c|}
\hline Description & Total & Percentages \\
\hline \multicolumn{3}{|l|}{ Gender: } \\
\hline Male & 152 & 85.4 \\
\hline Female & 26 & 14.6 \\
\hline \multicolumn{3}{|l|}{ Race: } \\
\hline Malay & 112 & 62.9 \\
\hline Chinese & 22 & 12.4 \\
\hline Iban & 40 & 22.5 \\
\hline Bugis & 4 & 2.2 \\
\hline \multicolumn{3}{|l|}{ Marital Status: } \\
\hline Single & 42 & 23.6 \\
\hline Married & 136 & 76.4 \\
\hline \multicolumn{3}{|l|}{ Number of children: } \\
\hline None & 16 & 9.0 \\
\hline 1-3 person & 68 & 38.2 \\
\hline 4-6 person & 90 & 50.6 \\
\hline 7-9 person & 4 & 2.2 \\
\hline \multicolumn{3}{|l|}{ Educational level: } \\
\hline None & 4 & 2.2 \\
\hline Formal education & 38 & 21.3 \\
\hline Primary school & 126 & 70.8 \\
\hline Highschool & 4 & 2.2 \\
\hline Diploma & 6 & 3.4 \\
\hline \multicolumn{3}{|l|}{ Occupation: } \\
\hline Self-employed & 152 & 85.4 \\
\hline Private sector & 16 & 9.0 \\
\hline Public sector & 10 & 5.6 \\
\hline
\end{tabular}

\subsection{Business profiles of oil palm smallholders}

Table 2 shows the business profiles of oil palm smallholders. There are six types of businesses with food and drink is the most popular. Second, 40 people are engaged in the retail business. Out of the total respondents, only 74 of them registered their business.

Most of the respondents started business with their own savings (144 people) while 16 borrowed from the bank is 16 people. Some had borrowed from Mara and other family members. According to Jasra et al. (2011), financial resources are very important to start business operation. A total of 18 people required RM400 to RM2000 to start their business. Fifty-six people (56) had an estimated net income of RM 250-RM 1000 per month while four others earn RM 9 001-RM 11000 per month.

Table 2: Business profiles of oil palm smallholders

\begin{tabular}{|c|c|}
\hline Descriptions & Total \\
\hline \multicolumn{2}{|l|}{ Business type: } \\
\hline Food and beverages & 52 \\
\hline Retails business & 40 \\
\hline Poultry & 10 \\
\hline Agriculture & 38 \\
\hline Apparel & 2 \\
\hline Oil palm related & 34 \\
\hline \multicolumn{2}{|c|}{ Years involved in business: } \\
\hline $1986-2000$ & 64 \\
\hline $2001-2005$ & 32 \\
\hline $2006-2010$ & 44 \\
\hline $2011-2015$ & 38 \\
\hline \multicolumn{2}{|l|}{ Type of registration: } \\
\hline No & 104 \\
\hline Registered & 74 \\
\hline \multicolumn{2}{|l|}{ Source of startup capital: } \\
\hline Personal saving & 144 \\
\hline Banks & 16 \\
\hline MARA & 4 \\
\hline Family members & 14 \\
\hline \multicolumn{2}{|c|}{ Amount of of startup capital: } \\
\hline $0400-2000$ & 82 \\
\hline $2001-4000$ & 46 \\
\hline $4001-6000$ & 24 \\
\hline $6001-8000$ & 16 \\
\hline $8001-10000$ & 10 \\
\hline \multicolumn{2}{|c|}{ Average net income from business: } \\
\hline $0250-1000$ & 25 \\
\hline $2001-3000$ & 56 \\
\hline $3001-7000$ & 52 \\
\hline $7001-9000$ & 20 \\
\hline $9001-11000$ & 4 \\
\hline
\end{tabular}

\subsection{Push and pull factors analysis}

Analysis using descriptive test against the push and pull factors indicated that all of the items showed the mean value of 2.5 and above. The results of these tests indicated that all items specified by respondents were important. While for outer loading test, there are a number of items deleted for not meeting the requirements of statistics. Value of outer loading for each factor item should equal or exceed 0.4 (Hulland, 1999).

As shown in Table 3, for push factor of family encouragement, deleted items are "business site provided by family", "encouragement family members to do business" and "family business continuity". For the income level factor, deleted items are "to expect high profits", "to receive extra income" and "to save for Hajj/umrah". There are two deleted items in the knowledge/skills factor such as "having knowledge and skills in business" and "having specific skills in a particular field". For leadership factor, there is one deleted item such as "high determinant". Meanwhile for pull factors, there are three items deleted from the factor of infrastructure facilities (refer to Table 4). 


\subsection{Evaluation of the model measurement}

The model measurement must meet the test criteria on Cronbach's Alpha (CA), Composite Reliability (CR), Average Extracted Variance (AVE) and Discriminant Validity Analyses. CA test showed values from 0.602 to 0.951 . The value indicates that all items were very strongly correlated (Hair et al., 2007). CA is considered to be excellent if value is equaled or exceeded 0.9 , very well if values are from 0.8 to 0.90 , good if values are from 0.7 to 0.8 , and admissible for values from 0.6 to 0.7 .

CR tests are used to ensure the reliability of internal consistency. CR test results found that all these factors had consistent values. While the values on Average Variance Extracted (AVE) are from 0.512 to 0.787 , the value must be at least 0.50 AVE (Chin, 1998). Discriminant validity is usually examined by comparing the square root of AVE with the correlations between the focal construct and all other constructs. The loading of each indicator is higher for its respective construct than for any other constructs (Chin, 1998). Discriminant validity between constructs is acceptably high when the square root of AVE for each construct exceeds the correlations between that and all other constructs (Table 5). Therefore, reliability analysis and validation used in this study showed good discriminant and convergent validities.

Table 3: Push factors in business

\begin{tabular}{|c|c|c|}
\hline Factors/Items & Mean & Outer Loading \\
\hline \multicolumn{3}{|l|}{ Business Opportunity (BO): } \\
\hline Take advantage of good econ conditions & 4.546 & 0.938 \\
\hline Free from office hour schedule & 4.335 & 0.764 \\
\hline Having the opportunity in business & 4.552 & 0.884 \\
\hline Having the site/business premises & 4.532 & 0.856 \\
\hline Collecting experience & 4.565 & 0.906 \\
\hline Dreams on having their own business & 4.611 & 0.930 \\
\hline \multicolumn{3}{|l|}{ Family Encouragement (FE): } \\
\hline Supports from friends & 3.855 & 0.631 \\
\hline The business site was provided by family & 3.559 & $\mathrm{X}$ \\
\hline Encouragement from family to do business & 3.440 & $\mathrm{X}$ \\
\hline Family business continuity & 3.184 & $\mathrm{X}$ \\
\hline $\begin{array}{c}\text { Desire to inherit the business to children } \\
\text { Income Level (IL): }\end{array}$ & 4.657 & 0.942 \\
\hline To generate family income & 4.828 & 0.948 \\
\hline To expect high profits & 4.348 & $\mathrm{X}$ \\
\hline To receive extra/side income & 4.381 & $\mathrm{X}$ \\
\hline To cover children's education cost & 4.756 & 0.929 \\
\hline To save for future/old days & 4.519 & 0.807 \\
\hline To save for Hajj/Umrah & 3.960 & $\mathrm{X}$ \\
\hline $\begin{array}{l}\text { Knowledge and Skill (KS): } \\
\text { Acknowledge the financial and capital position }\end{array}$ & 4.539 & 0.693 \\
\hline Having knowledge and skills in business & & \\
\hline To apply entrepreneurship lesson & 3.585 & $\begin{array}{c}\lambda \\
0.735\end{array}$ \\
\hline Had a business experience & 3.197 & 0.717 \\
\hline Having specific skills in certain field & 2.835 & $\mathrm{X}$ \\
\hline Risk / Challenges Management (RCM): & 4.078 & 0.963 \\
\hline $\begin{array}{l}\text { Foresee risks as business opportunity } \\
\text { Willing to take huge challenge in business }\end{array}$ & 4.072 & 0.900 \\
\hline \multicolumn{3}{|l|}{ Willing to take huge challenge in business } \\
\hline Understand the potential of business & 4.019 & 0.947 \\
\hline Use the strength of the business opportunities in the market & 4.414 & 0.659 \\
\hline Learning to take responsibility on their own & 4.407 & 0.763 \\
\hline & 4.473 & 0.677 \\
\hline \multicolumn{3}{|l|}{ Leadership Skill (LS): } \\
\hline High teamwork spirit & 4.447 & 0.856 \\
\hline Don't need the help of another person & 4.157 & 0.709 \\
\hline Able to communicate well with workers & 4.335 & 0.801 \\
\hline Able to ensure workers follow instructions & 4.335 & 0.728 \\
\hline Leadership values that helps in business & 4.250 & 0.846 \\
\hline Self-confidence & 4.671 & 0.662 \\
\hline High determinant & 4.651 & $\mathrm{X}$ \\
\hline Measure the self-capabilities & 4.585 & 0.883 \\
\hline
\end{tabular}

\subsection{The assessment of the structural model}

Fig. 1 show the path coefficient push and pull factors. The results of the test path coefficient of push factors indicate that all elements have positive relationships. First, income has a positive relationship $(\beta=0.177)$ in the respondent's engagement in business and they got involved in business due to income level $\left(\mathrm{t}=2.251^{* * *}\right)$. Second, family plays an important role for individuals who want to start business. This is shown with the results that family have a positive relationship and influence towards the participation of respondent in business. This shows that family encouragement have a positive element to continue the family business and gives positive feedback on respondents to engage in business. 
The assessment of business opportunities is important to ensure the continuity of the business. Respondents noted that opportunity is an important element in determining the business engagement and this is proven by the results of the test (t-test = 3.993) and significant at 0.01 significance level. Also, elements of knowledge and skills show and significant level. This implies that knowledge or skills in business have powerful push factor to engage in business. Next, elements of risk management related negative $(\beta=-0.186, \mathrm{t}=1.829$, $\mathrm{p}$-value $=0.01$ ). This is because the respondents had the opinion that risk and challenges are seen as business opportunity. Finally, leadership skill indicated that leadership is important to help respondents got involved in business. The results against the push factors indicated that all factors are important and also showed that the formation of a motivational push towards business $(\beta=0.306, \mathrm{t}$ test $=4.263^{* * *}$ ).

\begin{tabular}{ccc} 
Table 4: Pull factors & (External support) \\
\hline Factors/Items & Mean & Outer Loading \\
\hline Training (T): & \multicolumn{3}{c}{} \\
Marketing & 4.052 & 0.698 \\
Finance & 4.039 & 0.712 \\
Management & 3.697 & 0.942 \\
Technical & 3.756 & 0.916 \\
Infrastructure Facilities (IF): & \multicolumn{2}{|}{} \\
Sales premises/site & 3.776 & 0.999 \\
Machine & 3.953 & $\mathrm{X}$ \\
Water & 3.763 & $\mathrm{X}$ \\
Electricity & 3.960 & 0.531 \\
Internet & 3.467 & $\mathrm{X}$ \\
Finance(F): & \multicolumn{2}{|}{0.759} \\
Loan & 4.059 & 0.960 \\
Financial assistance & 4.098 & 0.968 \\
Profit sharing & 3.894 & 0.928
\end{tabular}

Table 5: Cronbach's alpha, composite reliability and average variance extracted

\begin{tabular}{cccc}
\hline Factors & $\begin{array}{c}\text { Cronbach's } \\
\text { Alpha }\end{array}$ & $\begin{array}{c}\text { Composite } \\
\text { Reliability }\end{array}$ & $\begin{array}{c}\text { Average Variance } \\
\text { Extracted (AVE) }\end{array}$ \\
\hline BO & 0.951 & 0.960 & 0.773 \\
FE & 0.602 & 0.776 & 0.643 \\
IL & 0.732 & 0.873 & 0.775 \\
KS & 0.640 & 0.758 & 0.512 \\
RCM & 0.904 & 0.927 & 0.685 \\
LS & 0.900 & 0.919 & 0.620 \\
T & 0.946 & 0.940 & 0.727 \\
IF & 0.664 & 0.765 & 0.640 \\
F & 0.888 & 0.916 & 0.787 \\
\hline
\end{tabular}

However, respondents still need external support factors to start a business. Test path coefficient and t-test on the attraction factors shows that there are essential three (3) elements to start a business. As shown in Fig. 1, factors of infrastructure facilities and training are important and relevant. However, the financial elements are less important to the respondent because most respondents began the business by using its own capital. The result is supported by Morrison (1996) that found small businesses did not need financial support because the transaction only involved a small environment and did not require a market share of production.

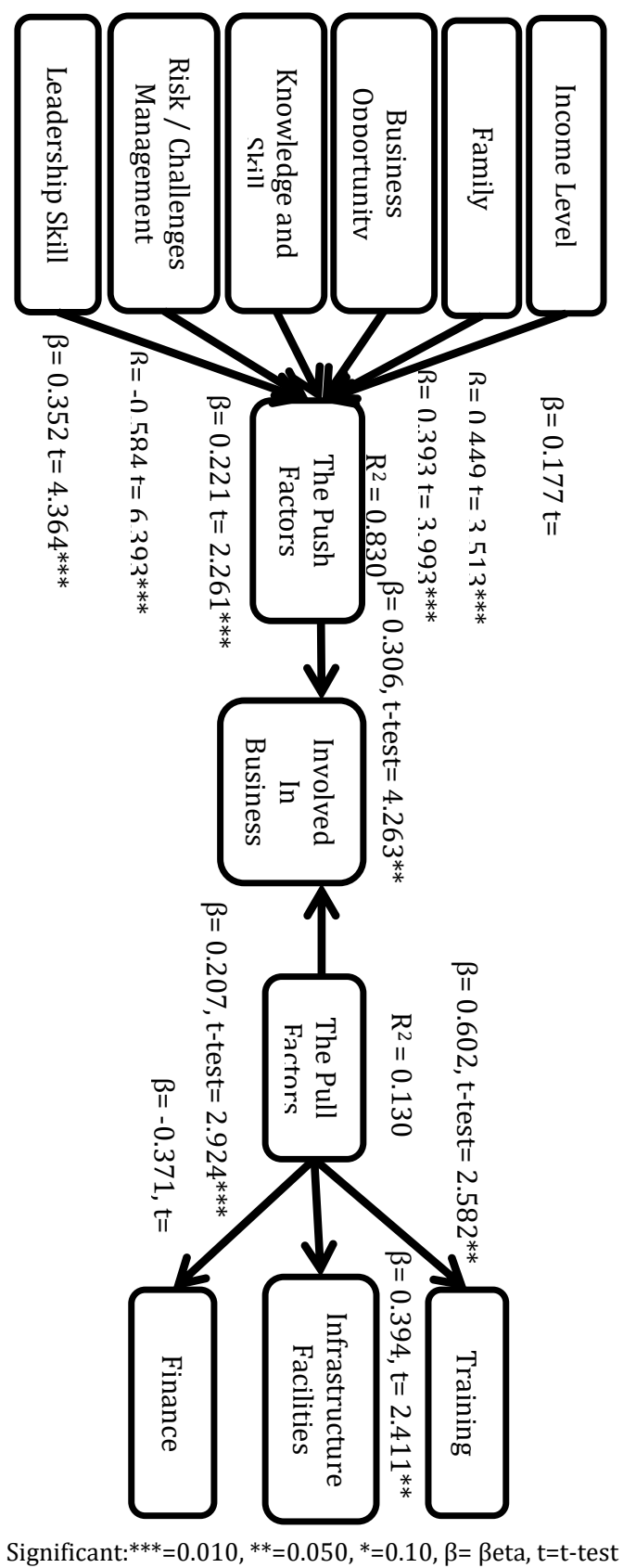

Fig. 1: Output research model

\section{Conclusion}

Rcommendations based on findings can be used as guidance by individuals who want to engage in business. This study proposed that business engagement is dependent on the push and pull factors in business. It is clear from the study that overall respondents got involved in business based on the push and pull factors.

The respondents stated that "risk/challenges management" is in the most important factor followed by "leadership skill", "business opportunity", "family encouragement", "knowledge and skills" and "income levels". Individuals involved in the business must have the vision to view business as a significant risk that can be dealt with. At the same time, they are also capable of analyzing their business position in order to compete healthily. In terms of leadership, enterpreneurs need to have a high degree of teamwork at both in lower or upper 
levels. This could help in the creation of new business innovations.

Individuals involved in business must take advantage of the business opportunity. However, they must identify the good economic climate so that their business won't be greatly affected with any economic turmoil. Factor on family encouragement is the emotional motivation related to engagement in business. Those involved in business usually want to pass their business to their children. This is because, they want to form the business legacy.

Enterpreneurs should have knowledge and skills such in dealing and negotiation. Experience will facilitate individuals in managing their business. Knowledge and skill could be gained by attending entrepreneurship and other relevant courses. For income, individuals need to have motivation to contribute more to the family income level since business can be one of the additional sources of income. In addition, people get into business with the intention to cover the cost of education for their children since the cost of education has increased over the years.

For pull factors, opportunity to attend "training" is most important. Followed by "infrastructure facilities" and "finance". Hence, individuals who wish to do business must be trained to follow certain ways so that the business will be more systematic. In addition, respondents agreed that infrastructure facilities are the most important element in the sales prenise. Therefore, relevant authority should play a role in providing the business site to enterpreneurs especially to the SMEs. Next, finance will be the least factor because most of the respondents are running small scale businesses. However, financial aids are essential for enterpreneurs to expand their business.

\section{References}

Alvarez SA and Busenitz LW (2001). The entrepreneurship of resource-based theory. Journal of Management, 27(6): 755775 .

Azhar A, Omar AR, Osman LH, Shukor MS, and Jusoh MA (2015). Oil palm smallholder's engagement in business activities. International Academic Research Journal of Social Science, 1(2): 192-198.

Chin WW (1998). The partial least squares approach to structural equation modeling. Modern Methods for Business Research, 295(2): 295-336.

Corso M, Martini A, Paolucci E, and Pellegrini L (2003). Knowledge management configurations in Italian small-to-medium enterprises. Integrated Manufacturing Systems, 14(1): 46-56.

Emin C (2000). Knowledge management as a competitive asset: A review. Marketing Intelligence and Planning, 18(4): 166-174.

Fishbein M and Ajzen I (1977). Belief, attitude, intention and behavior: An introduction to theory and research. Philosophy and Rhetoric, 10(2): 130-132.

Fuller PB (1994). Assessing marketing in small and medium-sized enterprises. European Journal of Marketing, 28(12): 34-49.

Gadar K and Yunus N (2009). The influence of personality and socio-economic factors on female entrepreneurship motivations in Malaysia. International Review of Business Research Papers, 5(1): 149-162.

Hair J, Money A, Samouel P, and Page M (2007). Research methods for business. John Wiley and Sons, New York, USA.

Hulland J (1999). Use of partial least squares (PLS) in strategic management research: A review of four recent studies. Strategic Management Journal, 20(2): 195-204.

Indarti N and Langenberg M (2004). Factors affecting business success among SMEs: Empirical evidences from Indonesia. In The $2^{\text {ed }}$ Bi-annual European Summer University, University of Twente, Encschede, Netherland: 19-25.

Jasra J, Khan M, Hunjra A, Rahman R, and Azam R (2011). Determinants of business success of SMEs. International Journal of Business and Social Science, 2(20): 275-280.

Jutla D, Bodorik P, and Dhaliwal J (2002). Supporting the ebusiness readiness of small and medium-sized enterprises: Approaches and metrics. Internet Research, 12(2): 139-164.

Kolawole 0 and Torimiro D (2005). Participatory and entrepreneurship development for grasstoots transformation: A factor analysis. Journal of Human Ecology, 18(3): 193-198.

Kuzilwa J (2005). The role of credit for small business success: A study of the national entrepreneurship development fund in Tanzania. The Journal of Entrepreneurship, 14(2): 131-161.

Mazdan A and Khiri M (2014). Personality dimensions towards entrepreneurship enculturation among graduates in Malaysia. International Journal of Arts and Commerce, 3(6): 85-93.

Morrison, A. (1996). Marketing the small tourism business. In: Seaton AV and Bennett M (Eds.), Marketing Tourism products: Concepts, issues and cases. International Thomson Publishing, London, UK.

MPOB (2014). Annual Report. The Malaysian Palm Oil Board, Bandar Baru Bangi, Malaysia. Available online at: http://www.mpob.gov.my/ms/info-sawit/alam-sekitar/520achievements

Page J, Forer P, and Lawton GR (1999). Small business development and tourism: Terra incognita? Tourism Management, 20(4): 435-459.

Rose R, Kumar N, and Yen L (2006). Entrepreneurs success factors and escalation of SMEs in Malaysia. Journal of Social Sciences, 2(3): 74-80.

Salleh NHM, Shukor MS, Othman R, Samsudin M, and Idris SHM (2016). Factors of local community participation in tourismrelated business: Case of langkawi island. International Journal of Social Science and Humanity, 6(8): 565-571.

Santrock JA (2007). Topical approach to life span development, McGraw-Hill, New York, USA.

Smit Y and Watkins JA (2012). A literature review of small and medium enterprises (SME) risk management practices in South Africa. African Journal of Business Management, 6(21): 63-74.

Vinten G (2000). Training in SMEs. Industrial and Commercial Training, 32(1): 9-14.

Walker E and Brown A (2004). What success factors are important to small business owners?. International Small Business Journal, 22(6): 577-594.

Yew K and Aspinwall E (2004). Characterizing knowledge management in small business environment. Journal of Knowledge Management, 8(3): 44-61.

Zapalska AM, Brozik D, and Zieser N (2015). Factors affecting success of small business enterprises in the Polish tourism industry. Turizam: Znanstveno-Stručni Časopis, 63(3): 365381. 